\title{
Customer Loyalty Analysis on Online Food Delivery Services
}

\author{
So Mario Sidharta ${ }^{\text {a }}$, Daniel Bagas Adityo ${ }^{\text {b }}$, Pangeran Muhammad Iqbal ${ }^{c}$, Willy Gunadi ${ }^{\mathrm{d}}$ \\ a,b,c,d Business Management Program, Management Department, BINUS Business School Master Program, Bina Nusantara \\ University, Jakarta, Indonesia, 11480
}

Article History: Received: 10 November 2020; Revised 12 January 2021 Accepted: 27 January 2021; Published online: 5 April 2021

\begin{abstract}
Indonesia's e-commerce growth has increased by $17 \%$ in the last ten years. One of the most popular e-commerce businesses in Indonesia is online food delivery services. Promotion is one of the reasons that makes online food delivery service users increase every year. This research aims in alayzing the effects of e-service quality (e-servqual), food quality, and sales promotion toward perceived value and customer satisfaction, as well as their impacts on customer loyalty. A questionnaire was distributed to 200 respondents who had used online food delivery services in DKI Jakarta. The Structural Equation Model (SEM) with the PLS-SEM was used to test the validity, reliability, and hypothesis. The results of this study indicate that customers satisfaction impacted customer loyalty, which is the benchmark for customers in using online food delivery services. Not only that, company's services, quality, and promotion impact customer satisfaction.
\end{abstract}

Keywords: online food delivery, e-service quality, food quality, sales promotion, customer loyalty

\section{Introduction}

Information technology is inseparable from social life since many modern activities depend on information technology. Technological advances that facilitate internet-based trading have changed people and businesses' behavior patterns. In 2018, Indonesia Internet Service Provider Association (APJII) states that the total Internet users in Indonesia were 171.17 million out of a total population of 264.16 million. This shows that $64.8 \%$ of the nation's population used the Internet. Web-based e-commerce applications are popular in Indonesia. This is a popular shopping platform as it allows users to simultaneously shop and compare products and prices, and determine immediate delivery (Chang et al., 2014; Yeo et al., 2017).

There has been a rise of $17 \%$ within the Indonesian e-commerce industry in the last ten years, resulting in the total number of approximately 26.2 million e-commerce business units, as stated by the Indonesian Central Statistics Agency (BPS) (Rahayu, 2019). The rapid growth in users of e-commerce was attributed to the rapid rise of smartphone users. Smartphones are much more affordable than other devices such as laptops and computers. According to Hirschberg et al. (2016), 75\% of online buyers in Indonesia use smartphones, and one of the most widely used e-commerce businesses is online food delivery services that are technically easy to use on smartphones. Consequently, it is generating considerable interest to analyze the online food delivery industry in Indonesia.

There are various reasons which influence the use of online delivery services in Indonesia. IDN TIMES.com (2019) states that those reasons include laziness to leave the house, promotions from applications, bad weather, saving time, and the considerable distance of the food outlet location. One of the reasons that online food delivery users have increased every year is the sales promotion provided by the company. Sales promotions provided by online food delivery vary widely, from collaborating with online payment services or using payment services from the online food delivery application itself for discount or voucher cashback, such as Go-Pay or OVO. Sales promotions tend to be done on a direct behavioural basis and not influencing awareness and attitude (Shultz, 1998). One purpose of sales promotion is to directly stimulate customers' purchase behaviours. Sales promotion significantly affects customers' satisfaction and plays an essential role in companies' sustainability, especially in online food delivery service (Hanaysha, 2017). Attractive sales promotions help companies win the competition.

In addition to promotion, service providers need to offer excellent services to satisfy customers (Bastiar, 2010). To provide the best service to customers, the online food delivery applications provide useful features, including a chat feature between users and drivers and a tracking feature to help customers track the driver's whereabouts. Furthermore, application providers need to pay attention to food quality since it is one of the basic factors of online food delivery (Namkung \& Jang, 2018). According to Saputro et al. (2014), consumers are focused on the quality of food. Hence consumers will be disappointed if the quality is decreased. Customers' disappointment and 
dissatisfaction will then affect and lower their loyalty (Paliati, 2007). Meanwhile, customer loyalty is critical because it provides excellent benefits for a company (Alma, 2002).

Many Indonesians who use this application mainly use online food delivery because the application provides various sales promotions (Wiryasti, 2019). The previous studies regarding the analysis of customer loyalty towards online food delivery service (Sjahroeddin, 2018; Suhartanto et al., 2018) did not relate the variable of sales promotion variable to be an indicator of customer satisfaction and perceived value in achieving customer loyalty. Meanwhile, Junaedi (2019) stated that sales promotion is a value that can provide a positive response to customer satisfaction making the users remain loyal in using it. Therefore, the aim for this research is to examine the correlation of e-servqual, food quality, promotion, perceived value, and satisfaction toward customers' loyalty toward online food delivery services.

\section{Literature Review}

\subsection{E-Commerce}

E-commerce is a mechanism by which buyers purchase and sell goods or services online and among companies through computers as a transaction medium (Laudon \& Laudon, 1998). According to Chaffey (2009), e-commerce is the exchange of electronic mediated financial transactions or information or services between a firm or stakeholders. The term e-commerce was coined from four various perspectives by Kalakota and Whinston (1997) which are; communication perspective including the delivery of goods, services, information, or payments; from the service perspective such as a tool that meets corporate and consumer needs; from the business process perspective such as an application of that technology that facilitates business transactions; and from the online perspective that is the ability to buy and sell goods or information via the internet. Seven types of e-commerce are currently developing; "Business to Business" (B2B), "Business to Consumer" (B2C), "Consumer to Consumer" (C2C), "Consumer to Business" (C2B), "Business to Administration"(B2A), "Consumer to Administration" $(\mathrm{C} 2 \mathrm{~A})$, and "Online to Offline" $(\mathrm{O} 2 \mathrm{O})$. These types of e-commerce develop along with the development of technology so that so many businesses of government, education, taxation, health, and retail can be developed and facilitated to simplify business processes. One of them is online food delivery, an online to offline (O2O) type of e-commerce.

\subsection{E-Service Quality (E-Servqual)}

Parasuraman (2005) defined that the assessment of e-service quality is done through the comparison of customers' expectations toward their previously perceived experiences. According to Zeithaml (2002), the quality of e-service refers to customer-inclusive evaluation of electronic services toward facilitating their purchase and delivery of goods and/or services. In addition, according to Santos (2003), the quality of e-service is an evaluation and assessment given by consumers based on the service quality in virtual form. Customers demand an outstanding level of website performance when online transacting (Caruana \& Ewing, 2010). This quality of website is crucial in retaining customers and their revisits, eventually securing their loyalty. As a result, the success of online businesses is affected by maintaining a highly qualified website (Parasuraman et al., 2005; Pee et al., 2018). A significant study was made which resulted in the measurement of e-service quality using four dimensions, which are system availability, performance, privacy, and fulfillment (Parasuraman, 2005)

\subsection{Food Quality}

The quality of food is a collection of customer requirements, which includes safety, commodity, nutritional value, and sensory (Peri, 2006). The quality of food is not a fundamental characteristic of food but more on acceptability (Issanchou, 1996). The term food quality includes inherent properties which determine the food suitability food for consumption, further processing, and storage, which includes retail display (Andersen et al. 2005). Quality can be seen as a dynamic and multivariate food property affected by several factors, which include the conditions of food production. The quality of food refers to the optimal quality of food in satisfying consumers' expectations and is considered to be an essential aspect of the restaurant experience (Ha \& Jang, 2010; Sulek \& Hensley, 2004). Indicators such as taste, nutrition and variety of food evoke customer loyalty and increase return visits. The use of menu, presentation, sizing, and variety are measurements in determining restaurant food quality (Liu et al. 2017). Characteristics that are commonly used to determine the foods' acceptability are health and dietary (Sulek and Hensley, 2004).

\subsection{Sales Promotion}

For companies to survive and have a competitive advantage, they must adopt effective and efficient promotional strategies. Sales promotion is characterized as a marketing practice that incites direct responses from customers or marketing intermediaries, and it is generally unique to a time, location or customer segment (Peattie $\&$ Peattie, 1994). Sale promotion is described to be both a main factor and key role of market success to determine the marketing mix for different products used to promote customers' purchase (Chaharsoughi, 2011). Large-scale 
promotions are used by companies to raise awareness among customers of the available products provided. Promotions are used as a tool to communicate with consumers. Adjagbodjou (2015) argued that sales promotion is an implementation that is often used by managers to directly influence the buying attitude of customers. Ochieng (2014) argued that sales promotions function more as an offensive strategy to attract customers to change the brand they use to the brand being promoted. It can be inferred that sales promotion is an activity informing the market on the goods or services available for transactions and encouraging the market to change brands.

\subsection{Perceived Value}

Perceived value is highly relevant for organisations, yet it is difficult to determine its commonly understood term by both marketers and researchers (Roig et al. 2006; Lin et al. 2005). Researchers and firms use perceived value interchangeably in referring to the values customers received from a product (Woodall, 2003). Kotler (2010) stated that perceived value is the difference of total customers' value and cost. Total customers' value refers to the perceived benefits that customers will gain from certain goods or services, whereas total customers' cost is expected to face in evaluating, obtaining, and using the goods or services. It is mentioned how perceived value is embedded in the theory of equity, which explained the exchange of monetary or non-monetary costs are equivalent to the value received by consumers (Yang and Peterson, 2004). Perceived value is the whole valuation of benefits from the goods or services received and provided (Lai, 2004). Flint and Woodruff (2001) argued that in the context of B2B, companies must face changes in perceived value where measuring these changes is very important to achieve a competitive advantage. Perceived value can be inferred as the combined value of advantages and sacrifices that customers received during the purchase.

\subsection{Customer Satisfaction}

Customers' satisfaction is among the top determinants for businesses to achieve success. Customer satisfaction is the satisfied or dissatisfied feelings that occurred after comparing their expectations toward the performance of the products and/or service (Kotler, 2002). Dissatisfaction occurs when the performance does not meet expectations, meanwhile satisfaction happens when performance exceeds customers' expectations. Customer satisfaction is then referred to customers' overall satisfied attitudes toward service providers or their emotional response to their expectations and received (Hansemark and Albinsson, 2004). It is stated that customers' satisfaction refers to the assessment made on whether customers' needs and expectations were met by the goods and/or services (Bitner and Zeithaml, 2003). The feeling of satisfaction does not result from the offered goods and/or services but customers' perception toward them (Boshoff and Gray, 2004). Hence, the same services will result in various customers' satisfactory responses (Ueltschy et al., 2007). According to Hill et al. (2007), customers satisfaction acts as a parameter in determining customers' future behaviours. Highly satisfied customers will tend to make repurchases and share their experiences with other potential consumers (Hague \& Hague, 2016). Hence, companies should maintain a good connection with their consumers.

\subsection{Customer Loyalty}

The food industry itself is a competitive and demanding market environment and has its customer satisfaction. They ensure business survival and a rise in success for the business (Ha \& Jang, 2010). Gaining customer loyalty is essential for business survival in a competitive market environment. Customer loyalty is the possibility of a customer making repeated purchases and is willing to become a partner for a company that products and services the company offer (Kotler, 2007). Thus, according to Jones and Sasser (1995), loyalty consumers are referred to consumers' behaviors in repeatedly using services due to feeling loyal to the company's products or services. With technological advancements, the term e-loyalty has arisen and broadens the science of traditional loyalty through the incorporation of technology in mediating the link of consumers and companies (Abou-Shouk \& Khalifa, 2017; Kim et al., 2009; Pee et al., 2018), which describes e-loyalty to be similar to customer loyalty and the web/application. Thus, loyalty to online food delivery services is a customer commitment that results in repeat purchases and positive things. There are several approaches to evaluating customer loyalty to service, namely behavioral loyalty as behavior that the concept of loyal customers as individuals who systematically buy products and/or services in a given time period (Suhartanto et al., 2018) and emotional loyalty that the concept of loyal customers is individuals who repurchase and vouch for companies (Gursoy et al., 2014).

\section{Hypothesis Development}

To enhance the competitiveness of a company and be sustainable, service quality should be maintained to generate perceived value and good customer satisfaction. Several studies have been conducted, focusing on examining the influence of e-service quality toward customers' satisfaction and perceived value. According to Cemal \& Elif (2016), e-service quality dimensions affect the perception of value. Cemal et al. (2014) stated that perceived value is positively impacted by e-service quality. Raditha et al. (2016) mentioned how both perceived 
value and customers satisfaction are influenced by quality of e-service. From the aforementioned discussion, the proposed hypothesis is developed:

H1. E-service quality has a positive influence on perceived value.

H2. E-service quality has a positive influence on customer satisfaction

The importance of food quality is crucial as it will help the business' survival and allow customers' satisfaction and perceived value to occur. Food quality for online food delivery is a standard that is maintained to ensure the quality of the food of the restaurant partners always to maintain quality because it affects the reputation of the company, the online food delivery itself. Regarding Indonesian food delivery services, Suhartanto et al. (2018) and Sjahroeddin (2018) studies mentioned how perceived value and customer satisfaction were positively influenced by food quality. Faruk (2019) also stated how positively influential food quality is toward both perceived value and customer satisfaction. Hence, the hypothesis is developed based on the above discussions:

H3. Food quality has a positive influence on perceived value.

H4. Food quality has a positive influence on customer satisfaction.

With how effective sales promotion is to attract consumers and increase sales, sales promotion should be strategized to educate consumers on new goods and services, further strengthening the business' competitiveness and profitability. Previous studies found that sales promotion positively impacted customer satisfaction and perceived value (Flynn et al., 2013; Bishop, 1984; Brodie et al., 2009; Caruana \& Ewing, 2010; Take et al., 2015; Haque, 2014; Marinescu et al., 2010; Heena \& Mansi, 2019). From the mentioned discussion, the hypothesis is as follows:

H5. Sales promotion has a positive influence on perceived value.

H6. Sales promotion has a positive influence on customer satisfaction.

When customers highly valued goods and/or services, the retention rate of customers will also be high (Naumann, 1995). The loyalty of customers resulted from their perceived value (Brodie et al., 2009; Hutchinson et al., 2009). Previous studies have determined that perceived value is a determinant of customer loyalty (Gill et al., 2007; Kim et al., 2008; Nasution \& Mavondo, 2008). With this, the hypothesis is developed as follows:

H7. Perceived value has a positive influence on customer loyalty.

Customers' trust is developed through the satisfaction of using goods and/or services, which also encourages repurchase. Customers' commitments in continuously purchasing and recommending the goods and/or services of a business are loyalty (Mellroy \& Barnett, 2000). Customer loyalty is formed by continuous customer satisfaction from the customer, which involves an emotional bond with the service provider or seller (Rai \& Medha, 2013). Studies made from various industries indicate that customer satisfaction and customer loyalty are positively linked (Chitty et al., 2007; Kim et al., 2008; Anderson \& Srinivasan, 2003; Pee et al., 2018). The hypothesis is developed as follows:

H8. Customer satisfaction has a positive influence on customer loyalty

Based on the hypotheses to be discussed, the model for this study is as follows.:

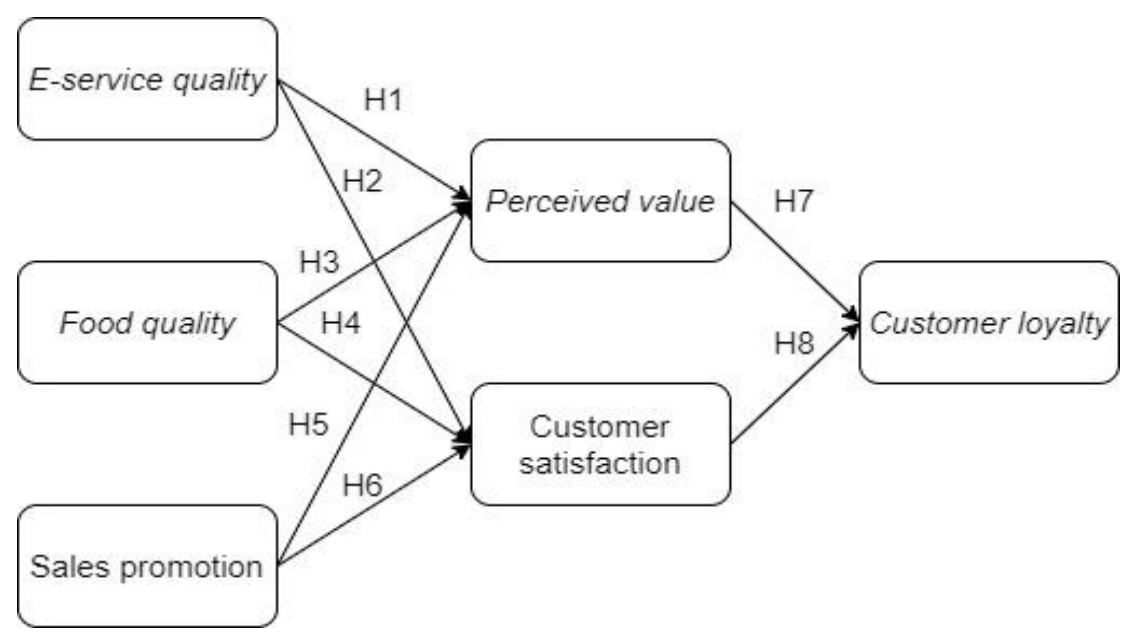

Figure 1 Research model 


\section{Research Method}

To achieve the objectives of the study, respondents were required to regularly use online food delivery at least three times a month. Respondents who met the criteria answered questions on demographic characteristics such as gender, age, marital status, education, occupation, average e-wallet top-up for online food delivery per month, and average transaction amount per month. Finally, they were asked to respond to a series of questions (indicators) using a five-point Likert scale ranging from "strongly disagree" to "strongly agree".

A pilot study was conducted to increase the validity of the instrument. A total of 30 online food delivery consumers were surveyed. In order to increase the readability of the questionnaire, some of the instrumentation was rephrased based on pilot study. A convenience sample was used due to the difficulty in obtaining the population of the survey respondents. The questionnaires were administered using social media (Instagram, facebook, etc), chat applications (whatsapp, snapchat, etc.), and linked to google forms. A total of 200 questionnaires were collected.

This study has six constructs, with each indicator construct describing a situation that occurs in the field and meets the context of the study. Five measurement items by Suhartanto et al. (2018) were adopted for e-service quality, food quality, and customer loyalty. Five measurement items for sales promotion were adopted from Zhang et al. (2017), Rizana et al. (2009), and Azriani (2012). Five measurement items for perceived value were taken from Suhartanto et al. (2018) and Putra (2019). Five measurement items for perceived value were applied from Suhartanto et al. (2018), Sjahroeddin (2018), Barsky et al. (2016), and Sinurat (2012).

The collected data were processed using the PLS-SEM method with the SmartPLS tool. In evaluating the outer model (measurement model), tests of validity and reliability were required. Convergent validity was determined from the average extracted variance (AVE) and the factor loadings; AVE and factor loadings must be higher than 0.5 , measurements that do not meet the requirements will be eliminated. The value of AVE squared root determined the discriminant validity is shown by the greater link of constructs (Hair et al., 2011), and reliability can be seen from the composite reliability value of 0.7 or higher. Once the tests of validity and reliability are done, the next step is to test between variables, that is, hypothesis testing. According to Hair et al. (2011), the critical tvalue for a two-tailed test is 1.96 (5\% significance level) and the p-value is less than 0.05 .

\section{Data Analysis}

An online questionnaire through Google Forms was used and distributed to 200 respondents who had used an online food delivery service at least three times in the past month. Table 1 shows the respondents' characteristics.

Table 1 Respondent Characteristics ( $\mathrm{N}=200)$

\begin{tabular}{|c|c|c|c|}
\hline Characteristic & Category & Total & Percentage \\
\hline Gender & $\begin{array}{ll}\text { 1. } & \text { Male } \\
2 . & \text { Female }\end{array}$ & $\begin{array}{l}147 \\
53\end{array}$ & $\begin{array}{l}\mathbf{7 3 , 5 \%} \\
26,5 \%\end{array}$ \\
\hline Age & $\begin{array}{ll}3 . & <25 \text { years old } \\
\mathbf{4 .} & \mathbf{2 5}-\mathbf{3 4} \text { years old } \\
5 . & 35-44 \text { years old } \\
6 . & 45-54 \text { years old } \\
7 . & >54 \text { years old } \\
\end{array}$ & $\begin{array}{l}57 \\
\mathbf{1 1 5} \\
16 \\
7 \\
5\end{array}$ & $\begin{array}{l}28,5 \% \\
\mathbf{5 7 , 5 \%} \\
8 \% \\
3,5 \% \\
2,5 \%\end{array}$ \\
\hline Status & $\begin{array}{ll}\text { 1. } & \text { Married } \\
\text { 2. } & \text { Single } \\
\end{array}$ & $\begin{array}{l}52 \\
148\end{array}$ & $\begin{array}{l}26 \% \\
74 \% \\
\end{array}$ \\
\hline Education & $\begin{array}{ll}\text { 1. } & \text { Senior High School } \\
\text { 2. } & \text { Diploma } \\
\text { 3. } & \text { Bachelor Degree } \\
\text { 4. } & \text { Master Degree } \\
\text { 5. } & \text { Doctoral } \\
\end{array}$ & $\begin{array}{l}7 \\
4 \\
\mathbf{1 6 8} \\
20 \\
1 \\
\end{array}$ & $\begin{array}{l}3,5 \% \\
2 \% \\
\mathbf{8 4 \%} \\
10 \% \\
0,5 \% \\
\end{array}$ \\
\hline Occupation & $\begin{array}{ll}\text { 1. } & \text { Student } \\
\text { 2. } & \text { Employee } \\
\text { 3. } & \text { Entrepreneur } \\
\text { 4. } & \text { Pension } \\
\end{array}$ & $\begin{array}{l}13 \\
154 \\
29 \\
4\end{array}$ & $\begin{array}{l}6,5 \% \\
77 \% \\
14,5 \% \\
2 \% \\
\end{array}$ \\
\hline Budget for e-wallet top up & $\begin{array}{ll}\text { 1. } & \text { Rp. }<\mathbf{5 0 0 . 0 0 0} \\
2 . & \text { Rp. } 500.000-1.000 .000 \\
\text { 3. } & \text { Rp. }>1.000 .000\end{array}$ & $\begin{array}{l}112 \\
77 \\
11\end{array}$ & $\begin{array}{l}\mathbf{5 6 \%} \\
38,5 \% \\
5,5 \% \\
\end{array}$ \\
\hline Budget in one month & $\begin{array}{ll}1 . & \text { Rp. }<100.000 \\
\text { 2. } & \text { Rp. 100.000 - 500.000 } \\
\text { 3. } & \text { Rp. } 501.000-1.000 .000 \\
\text { 4. } & \text { Rp. }>1.000 .000\end{array}$ & $\begin{array}{l}12 \\
\mathbf{1 2 5} \\
52 \\
11\end{array}$ & $\begin{array}{l}6 \% \\
\mathbf{6 2 , 5 \%} \\
26 \% \\
5,5 \%\end{array}$ \\
\hline
\end{tabular}


From the above data, we can see that $73.5 \%$ of the respondents are male and $57.5 \%$ are in the age group of 25 34. Most of the respondents are not married (74\%) and most of the respondents' education level is bachelor degree (84\%). The highest occupation of the respondents is employee, with $77 \%$ of the respondents. Majority of the respondents have a top-up <Rp. 500,000 (56\%), and the average transaction expenditure in the past month is between Rp. 100,000 and Rp. 500,000, 62.5\%.

Table 2 shows the validity and reliability test results by analyzing the factor loading, AVE, and composite reliability values. To verify the data is valid, the loading factor and AVE values must be greater than 0.5. In Table 2 , the results show that the measurement is valid, determined by the AVE values and loading coefficients for all variables being above 0.5 . To determine the measurement's reliability, composite reliability was applied, and the value of composite reliability analysis must be 0.7 or higher. From the results shown in Table 2 , the composite reliability values of all variables are 0.7 or higher, which states that the measurement is reliable.

Table 2 Reliability and Validity Results

\begin{tabular}{|c|c|c|c|c|c|}
\hline Variabel & Item & $\begin{array}{l}\text { Factor } \\
\text { Loading }\end{array}$ & Mean & $\begin{array}{l}\text { Composite } \\
\text { Reliability }\end{array}$ & $\begin{array}{l}\text { Average } \\
\text { Variance } \\
\text { Extracted }\end{array}$ \\
\hline $\begin{array}{l}\text { E-service } \\
\text { Quality }\end{array}$ & $\begin{array}{l}\text { ES1 : Online food delivery apps made it easy for me to find } \\
\text { my desired needs. } \\
\text { ES3 :Online food delivery apps are always available. } \\
\text { ES4 : The delivery time made by the online food delivery } \\
\text { application will always be on time. }\end{array}$ & $\begin{array}{l}0.816 \\
0.568 \\
0.738\end{array}$ & $\begin{array}{l}4.74 \\
4.81 \\
3.77\end{array}$ & 0.785 & 0.557 \\
\hline Food Quality & $\begin{array}{l}\text { FQ1 : The serving of food ordered through the online food } \\
\text { delivery application is in accordance with the display in the } \\
\text { application. } \\
\text { FQ4 : The online food delivery application offers healthy } \\
\text { menu. }\end{array}$ & $\begin{array}{l}0.845 \\
0.779\end{array}$ & $\begin{array}{l}3.84 \\
4.00\end{array}$ & 0.772 & 0.640 \\
\hline $\begin{array}{l}\text { Sales } \\
\text { Promotion }\end{array}$ & $\begin{array}{l}\text { P1 : The promotions offered by online food delivery apps } \\
\text { are attractive. } \\
\text { P2: The special price promotions offered in the online food } \\
\text { delivery application are useful to me. } \\
\text { P3 : Promotions in the form of coupons offered by online } \\
\text { food delivery applications according to my needs. } \\
\text { P4: The point exchange feature on online food delivery is } \\
\text { useful for me. }\end{array}$ & $\begin{array}{l}0.772 \\
0.843 \\
0.783 \\
0.765\end{array}$ & $\begin{array}{l}4.35 \\
4.45 \\
3.94 \\
3.84\end{array}$ & 0.811 & 0.522 \\
\hline $\begin{array}{l}\text { Perceived } \\
\text { Value }\end{array}$ & $\begin{array}{l}\text { PV1: The prices offered by the online food delivery app are } \\
\text { affordable. } \\
\text { PV2: It is convenient to order through online food delivery } \\
\text { app. } \\
\text { PV3: Transactions on online food delivery have good value. }\end{array}$ & $\begin{array}{l}0.653 \\
0.679 \\
0.840\end{array}$ & $\begin{array}{l}3.90 \\
4.45 \\
4.35\end{array}$ & 0.724 & 0.683 \\
\hline $\begin{array}{l}\text { Customer } \\
\text { Satisfaction }\end{array}$ & $\begin{array}{l}\text { S1: I am satisfied with the use of the online food delivery } \\
\text { application. } \\
\text { S2: The experience when using the application is as } \\
\text { expected. } \\
\text { S4: I am satisfied with the tenants of the online food } \\
\text { delivery application. } \\
\text { S5: The online food delivery application meets all my } \\
\text { expectations. }\end{array}$ & $\begin{array}{l}0.734 \\
0.771 \\
0.696 \\
0.785\end{array}$ & $\begin{array}{l}4.39 \\
4.32 \\
4.26 \\
4.26\end{array}$ & 0.869 & 0.625 \\
\hline $\begin{array}{l}\text { Customer } \\
\text { Loyalty }\end{array}$ & $\begin{array}{l}\text { L1: I would like to continue to use online food delivery } \\
\text { apps to order food. } \\
\text { L2: I would encourage others to use food delivery apps. } \\
\text { L3: I would introduce the food delivery app to others. } \\
\text { L4: I would continue to order from the online food delivery } \\
\text { app even if there is a price increase. }\end{array}$ & $\begin{array}{l}0.734 \\
0.789 \\
0.819 \\
0.770\end{array}$ & $\begin{array}{l}4.32 \\
4.39 \\
4.29 \\
3.90\end{array}$ & 0.939 & 0.794 \\
\hline
\end{tabular}

Respondents were most attracted by sales promotional activity involving "special price" (with a mean score of 4.45), whereas "point exchange" were the least attractive (3.84). Consumers were more satisfied with online food delivery service "availability" (4.81) than with the "delivery time" (3.77). The item that generated the most 
favorable perceptions of value was "convenient" (4.45), and the one that elicited the least favorable perceptions of value was "price is affordable" (3.90).

In Table 3, the validity of measurement was analysed using discriminant validity. In this case, it is necessary to show the value of AVE square root to be more significant compared to the correlation of each value construct. In this study, the value of each variable of AVE square root is greater than the correlation value of each construct, indicating the discriminant validity to be satisfied.

Table 3 Discriminant Validity Results

\begin{tabular}{|l|l|l|l|l|l|l|}
\hline & $\begin{array}{l}\text { Customer } \\
\text { Loyalty }\end{array}$ & $\begin{array}{l}\text { Customer } \\
\text { Satisfaction }\end{array}$ & $\begin{array}{l}\text { E-service } \\
\text { Quality }\end{array}$ & $\begin{array}{l}\text { Food } \\
\text { Quality }\end{array}$ & $\begin{array}{l}\text { Sales } \\
\text { Promotion }\end{array}$ & $\begin{array}{l}\text { Perceived } \\
\text { Value }\end{array}$ \\
\hline $\begin{array}{l}\text { Customer } \\
\text { Loyalty }\end{array}$ & $\mathbf{0 , 7 7 9}$ & & & & & \\
\hline $\begin{array}{l}\text { Customer } \\
\text { Satisfaction }\end{array}$ & 0,484 & $\mathbf{0 , 7 4 8}$ & & & & \\
\hline $\begin{array}{l}\text { E-service } \\
\text { Quality }\end{array}$ & 0,428 & 0,591 & $\mathbf{0 , 7 1 5}$ & & & \\
\hline Food Quality & 0,260 & 0,329 & 0,295 & $\mathbf{0 , 8 1 3}$ & & \\
\hline Sales Promotion & 0,418 & 0,474 & 0,430 & 0,290 & $\mathbf{0 , 7 9 1}$ & \\
\hline Perceived Value & 0,535 & 0,530 & 0,546 & 0,207 & 0,570 & $\mathbf{0 , 7 2 9}$ \\
\hline
\end{tabular}

Table 4 displays the hypothesis analysis results of the research. This analysis test was conducted using SmartPLS and one of the eight hypotheses was rejected.

Table 4 Hypothesis Test Results

\begin{tabular}{|l|c|c|c|}
\hline Path & Path coefficient & $\begin{array}{c}\text { t- } \\
\text { statistic }\end{array}$ & p-value \\
\hline E-Service Quality $\rightarrow$ Perceived Value & 0,375 & 4,389 & 0,000 \\
\hline E-Service Quality $\rightarrow$ Satisfaction & 0,449 & 5,415 & 0,000 \\
\hline Food Quality $\rightarrow$ Perceived Value & $-0,025$ & 0,386 & 0,699 \\
\hline Food Quality $\rightarrow$ Satisfaction & 0,126 & 1,945 & 0,052 \\
\hline Sales Promotion $\rightarrow$ Perceived Value & 0,416 & 5,240 & 0,000 \\
\hline Sales Promotion $\rightarrow$ Satisfaction & 0,244 & 2,792 & 0,005 \\
\hline Perceived Value $\rightarrow$ Loyalty & 0,387 & 4,935 & 0,000 \\
\hline Satisfaction $\rightarrow$ Loyalty & 0,279 & 3,373 & 0,001 \\
\hline
\end{tabular}

In hypothesis testing, R-squared analysis is also conducted, in which R-squared serves as a coefficient of determination that represents the proportion of variance in the dependent variable described by the independent variable in the research model (Rights \& Sterba, 2018). In this case, an R-square with a value of 0.75 is said to be a substantial model, 0.50 is moderate, and 0.25 is low (Hair et al., 2014).

The data process of r-squared perceived value variable result shows 0.437 , which suggests that $43.7 \%$ of the perceived value $(\mathrm{PV})$ variable can be explained by e-service quality, food quality, and sales promotion variables. Meanwhile, this study does not explain the remaining $56.3 \%$ of other variables. The customer satisfaction Rsquared value shows 0.423 . This indicates that the variables e-service quality, food quality, and sales promotion can explain as much as $42.3 \%$ of customer satisfaction variables and $57.7 \%$ of which other variables were not explained in this study. The result of data processing for the r-squared value of the perceived value (PV) variable was 0.342 . This shows how $34.2 \%$ of customer loyalty was explained through perceived value and customer satisfaction, whereas $65.8 \%$ of other variables were not explained in the study. The trust level used in this analysis is $95 \%$, so based on the t-statistic, the minimum t-value that must be achieved to be declared as having a significant influence is greater than 1.96, and the hypothesis is accepted if the p-value is less than 0.05 . 


\section{Discussion}

As a provider of online food delivery services, numerous aspects need further discussion to enforce the organisation's sustainability. These aspects are required to be able to have a good impact on the company in order to maintain customer loyalty. A study conducted indicates eight hypotheses to be considered by online food delivery service providers to gain loyalty from customers. Data were analyzed using smartPLS.

The data analysis that had been carried out shows that some hypotheses had a significant positive impact. Perceived value and customers satisfaction were significantly impacted by e-service quality. This indicates how advantageous e-service quality is toward online food delivery services, and positively impacted customers satisfaction. These findings confirm studies conducted by Suhartanto et al. (2018), Cemal et al. (2014), and Elif et al. (2014), where their studies illustrate that application services are one of the media used by users to make transactions. Accordingly, appearance and ease of use are essential in online food delivery services. Regarding customer satisfaction, previous studies state how user satisfaction is the reflection of users' expectations of an online food delivery application (Suhartanto et al. 2018; Kedah et al. 2015). If the customer's expectations of the service are higher than their perception, the consumer is pleased with the service.

There was one hypothesis of this study that did not have a significant impact, which is the impact of food quality toward perceived value and customer satisfaction. Customers' perceived value was not affected by food quality. Food quality conditions in the online food delivery application, such as serving food according to the appearance in the application and the absence of a healthy menu, were assessed as having no impact on users' value of online food delivery. The results of this hypothesis testing were not aligned with several previous research (Brodie et al. 2009; Hutchinson et al. 2009; Suhartanto et al. 2018) which state how perceived value is positively impacted by quality of food. Apart from that, regarding customer satisfaction, an interview conducted with one of the online food delivery users on the quality of food delivery showed that this study were not following the studies of Suhartanto et al. (2018), Sjahroeddin (2018), and Faruk (2019) which state how the correlation of food quality and customer satisfaction was significantly influential.

Sales promotion significantly affected perceived value and customer satisfaction. Hypothesis test results show that sales promotions provide by e-commerce companies were added value for users, where the promotions are given were one of the attractions for users to use the application. The offered promotions lead users to be satisfied in using the application. The results obtained are aligned to previous studies by Huang et al. (2014) and Park \& Lenon (2007), where promotion is one of the added values of every product marketed, with the promotion of users or customers interested in buying or using the services.

Customer loyalty is one aspect that is the goal of every company. It was shown how customer loyalty was positively affected by customer satisfaction. Users can be loyal to online food delivery service providers if they feel that they are getting higher than what they sacrifice. Besides, in terms of customer satisfaction at online food delivery companies, the application users feel satisfied with the transaction activity carried out by them, making them satisfied and loyal. Previous studies that explained how user loyalty depicts online food delivery values (Suhartanto et al. 2018; Brodie et al. 2009; Hutchinson et al. 2009) support the results gathered from this study. If the results obtained by users are higher, then users feel they can be loyal to the service. Customer satisfaction in online food delivery companies makes application users feel satisfied since the transaction activities carried out by them on the platform make them satisfied and loyal. In terms of customer satisfaction, this study follows a research by Suhartanto et al. (2018) that explains how satisfied and loyal users toward online food delivery applications will make repeat purchases and recommend online food delivery applications to others.

\section{Conclusions}

Customer loyalty is an important thing for companies to pay attention to, especially in the service businesses such as online food delivery. This study proves that customer loyalty is influenced by customer satisfaction, a benchmark for customers using online food delivery services. Customer satisfaction is also caused by several things such as service, quality, and promotion provided by the company to form customer satisfaction to its customers. The respondents involved in this study were mostly in the age range of 25 to 34 and worked as employees who want everything to be easy and fast. Therefore, with all the convenience of making transactions using online food delivery, customers feel satisfied and obtain added value. Thus, online food delivery is useful for their daily use.

Besides customer satisfaction, another factor that affects customer loyalty is perceived value. Customeracquired values tend to have effects on perceived value, such as the advantages of using online food delivery. The main reason why respondents used online food delivery services is the benefits and needs received by users. Thus, the time spent on buying food traditionally can be used for more benefits such as doing work or other activities.

Consumers' satisfaction and values impact their loyalty toward online food delivery services, resulting in their positive attitude to the services. The customer's positive attitude makes customers loyal. Accordingly, customers 
are satisfied with the service, willing to make repeat purchases, and are willing to recommend others. It can also be seen from the frequency of transactions from the old user or new user.

Moreover, this study also examined the quality of food in online food delivery services. However, food quality did not affect customer satisfaction and perceived value. Customers considered that food quality in online food delivery refers more to secondary needs, where the primary need needed is food that is delivered on time and according to the order.

\section{Managerial Implication}

Based on the study findings on online food delivery applications, there are managerial implications for service providers, especially online food delivery systems. This study indicates that the quality of e-service is considered necessary by users. In this study, one of the factors that the company must consider is the suitability of time in the application. Therefore, the company has to analyze and improve the estimated time given in the application by improving its system in detecting the driver's location when submitting orders to the drivers to suit the location of purchase/pick-up.

Meanwhile, in the sense of sales promotion, online food delivery providers can rely more on discount deals than loyalty points. This study's findings show that consumers of online food delivery systems consider discounts to be more valuable than loyalty points offered by service providers. On the other hand, the company can convert reward points, which are converted into direct prizes such as "if you buy 3 times, you will get 1 for free." Thus, users can benefit from promotions given directly in real-time.

Moreover, online food delivery service providers also should pay more attention to food quality. A company can ensure that tenants have acceptable packaging standards. Moreover, the company can also facilitate its partners with heat-resistant bags. Thus, the quality of food can be maintained during the delivery and the customers can be satisfied with the services provided.

The last thing that has to be paid attention to by the online food delivery companies is food safety. After the food quality can be maintained, a company needs to ensure food safety until it reaches customers. In such situations, the company must ensure that the driver or its partner does not touch or take the user's food delivered. To solve this matter, a company can hold socialization to tenants to seal their food packaging. Sealing the food packaging aims to keep the food safe from being consumed or opened by others, including the driver of online food delivery companies.

\section{Suggestion For Future Studies}

In addition to research on online food delivery companies, a study can also be carried out on document or goods delivery services for many applications that have started to offer these services. Moreover, some conventional shipping companies have begun to switch to using online application system to adapt to the trends. This condition requires further analysis because companies are starting to shift their business operations from conventional to online. With further studies, if there is a shortage in this kind of business, the company can immediately create improvements to meet the customers' needs and desires. Besides document delivery services, drug delivery services are also interesting because more and more applications offer services to purchase and deliver drugs, especially amid a pandemic.

\section{References}

Adjagbodjou, P. (2015). Aligning Sales Promotion Strategies with Buying. Walden University.

Arikunto, S. (2010). Prosedur penelitian: suatu pendekatan praktik. Jakarta: rineka cipta.

Asosiasi Penyelenggara Jasa Internet Indonesia. (2018). https://www.apjii.or.id/. Retrieved from https://www.apjii.or.id/survei

Bitner, M. J., \& Zeithaml, V. A. (2003). Service Marketing: Integrating Customer Focus across the Firm. New York.

Boshoff, C., \& Gray, B. (2004). The Relationship Between Service Quality, Customer Satisfaction and Buying Intentions in the Private Hospital Industry. South African Journal of Business Management, 35(4), 27-37.

Caruana, A., \& T. Ewing, M. (2010). How corporate reputation, quality, and value influence online loyalty. Journal of Business Research, 63(9), 1103-1110.

Cha, J., \& Borchgrevink, C. P. (2018). Customers' perceptions in value and food safety on customer satisfaction and loyalty in restaurant environments: moderating roles of gender and restaurant types. Journal of Quality Assurance in Hospitality \& Tourism, 1-19.

Chaffey, D. (2009). E-Business and e-commerce management: strategy. Prentice Hall.

Chaharsoughi, S. A. (2011). The Affect Of Sales Promotion On Consumer Interest To Purchase In IKCO Automotive Company. Journal of Knowledge Management, Economics and Information Technology(4), 1-3. 
Chen, Q., Huang, R., \& Hou, B. (2020). Perceived authenticity of traditional branded restaurants (China): impacts on perceived quality, perceived value, and behavioural intentions. Current Issues in Tourism, 1-22.

Chin, W. W., \& Newsted, P. R. (1999). Structural Equation Modeling Analysis with Small Samples Using Partial Least Square. In Statistical strategies for small sample research (pp. 307-341). Sage Publications.

Chitty, B., Ward, S., \& Chua, C. (2007). An application of the ECSI model as a predictor of satisfaction and loyalty for backpacker hostels. Marketing Intelligence \& Planning, 25(6), 563-580.

Flint, D. J., \& Woodruff, R. B. (2001). The Initiators of Changes in Customers' Desired Value. Industrial Marketing Management, 321-337.

Foruk, \& Konuk. (2019). The influence of perceived food quality, price fairness, perceived value and satisfaction on customers' revisit and word-of-mouth intentions towards organic food restaurants. Journal of Retailing and Consumer Services, 50, 103-110.

Gill, D., Byslma, B., \& Ouschan, R. (2007). Customer perceived value in a cellar door visit: the impact on behavioural intentions. International Journal of Wine Business Research, 19(4), 257-275.

Han, H., Lee, K.-S., Chua, B.-L., Lee, S., \& Kim, W. (2019). Role of airline food quality, price reasonableness, image, satisfaction, and attachment in building re-flying intention. International Journal of Hospitality Management, 80, 91-100.

Hague, P., \& Hague, N. (2016). Customer Satisfaction Survey: The customer experience through the customer eyes. London: Cogent Publication.

Hanaysah, J. R. (2017). Impact of Social Media Marketing, Price Promotion, and Corporate Social Responsibility on Customer Satisfaction. SAGE.

Hapsari, R., Clemesa, M., \& Dean, D. (2016). The Mediating Role of Perceived Value on the Relationship between Service Quality and Customer Satisfaction: Evidence from Indonesian Airline Passengers. 7th International Economics \& Business Management Conference, 35, 388-395.

Heena, U., \& Mansi, K. (2019). Key Success Factors of Online Food Ordering Services in Indore City. Journal of Advances and Scholarly Researches in Allied Education, 16(6), 340-345.

Hill, N., Roche, G., \& Allen, R. (2007). Customer Satisfaction: The customer experience through the customer's eyes. London: Cogent Publishing Ltd.

Hischberg, C., Rajko, A., Schumaker, T., \& Wrulich, M. (2016, 11 9). https://www.mckinsey.com/. Retrieved from https://www.mckinsey.com/industries/technology-media-and-telecommunications/our-insights/thechanging-market-for-food-delivery

Huang, H.-C., Chang, Y.-T., Yeh, C.-Y., \& Liao, C.-W. (2014). Promote the price promotion The effects of price promotions on customer evaluations in coffee chain stores. International Journal of Contemporary Hospitality Management, 26(7), 1065-1082.

Hutchinson, J., Lai, F., \& Wang, Y. (2009). Understanding the relationships of quality, value, equity, satisfaction, and behavioral intentions among golf travelers. Tourism Management, 298-308.

IDNTIME Team. (2019, 2 19). https://www.idntimes.com. Retrieved from https://www.idntimes.com/food/dining-guide/putriana-cahya/millennials-kecanduan-pesan-antar-makananhemat-waktu-atau-malas/full

J.Brodie, R., R.M.Whittome, J., \& J.Brush, G. (2009). Investigating the service brand: A customer value perspective. Journal of Business Research, 62(3), 345-355.

Kedah, Z., Ismail, Y., Ahasanul, A. K., \& Ahmed, S. (2015). Key Success Factors of Online Food Ordering Services: An Empirical Study. Malaysian Management Review, 50(2), 19-36.

Kim, K., Jeong, I., Park, J., Park, Y., Kim, C., \& Kim, T. (2008). The impact of network service performance on customer satisfaction and loyalty: high-speed internet service case in Korea. Expert Systems with Applications, 32(3), 822-831.

Kompas Team. (2017, $12 \quad$ 14). https://tekno.kompas.com/. Retrieved from https://tekno.kompas.com/read/2017/12/14/11174227/pengguna-go-jek-temui-fitur-chat-dengan-driver

Kothari, C. (2004). Research Methodology: Methods and Techniques. 2nd Edition. New Delhi: New Age International Publishers.

Kotler, P. (2002). Manajemen Pemasaran. Jakarta: PT Prenhallindo.

Kotler, P. (2010). Manajemen Pemasaran. Edisi tiga belas . Jakarta: Erlangga.

Lin, C.-H., Sher, P. J., \& Shih, H.-Y. (2005). Past progress and future directions in conceptualizing customer perceived value. International Journal of Service Industry Management, 7(1), 318-336.

Liu, Y., \& Jang, S. (2009). Perceptions of Chinese restaurants in the U.S.: What affects customer satisfaction and behavioral intentions? International Journal of Hospitality Management, 28, 338-348.

Marinescu, P., Mihai, N. S., \& Toma, S. (2010). Pricing strategy used as a tool for building customer satisfaction in the retail sector. Science, 60-80.

Mbango, P. (2019). The role of perceived value in promoting customer satisfaction: Antecedents and consequences. Cogent Social Science.

Nasution, H., \& Mavondo, F. (2008). Customer value in the hotel industry: what managers believe they deliver and what customer experience. International Journal of Hospitality Management, 27(2), 204-213. 
Nikhashemia, S., Tarofderb, A., Gaura, S. S., \& Haque, A. (2016). The Effect of Customers' Perceived Value of Retail Store on Relationship between Store Attribute and Customer Brand Loyalty: Some Insights from Malaysia. Fifth International Conference On Marketing and Retailing, 37, 432-438.

Ochieng, O. M. (2014). The Influence of Sales Promotion Strategies on Consumer Behaviour In The Alcoholic Spirits Industry in Nairobi Central Business District. University of Nairobi.

Parasuraman, A. P., Malhotra, A., \& Zeithaml, V. A. (2005). E-S-Qual: A Multiple-Item Scale for Assessing Electronic Service Quality. SAGE, 7(3), 213-233.

Peattie, S., \& Peattie, K. (1994). Promoting Financial Services with Glittering Prizes. International Journal of Bank Marketing, 19-29.

Pee, L. G., Jiang, J., \& Klein, G. (2018). E-Store Loyalty: Longitudinal Comparison of Website Usefulness and Satisfaction. International Journal of Market Research, 60(1), 1-17.

Pratiwi, H., Rosmawati, P., \& Usman, O. (2018). Effect of Price, Promotion, Brand Trust, and Customer Satisfaction on Customer Loyalty in Packaging Products Mineral Water Aqua. University of Jakarta.

Rahayu, N. (2019, 2 19). https://www.wartaekonomi.co.id. Retrieved from https://www.wartaekonomi.co.id/read216302/pertumbuhan-e-commerce-pesat-di-indonesia

Rai, A. K., \& Srivastava, M. (2013). The Antecedents of Customer Loyalty: An Empirical Investigation in Life Insurance Context. Journal of Competitiveness, 5(2), 139-163.

Rasmansyah. (2017). The effect of service quality and promotion to customer satisfaction and implication of customer loyalty in vehicle financing company in Jakarta, Indonesia. International Journal of Advanced Scientific Research, 2(6), 22-30.

Schultz DE, Robinson WA (1998) Sales Promotion Management, Chicago: Crain Books

Sekaran, U., \& Bougie, R. (2016). Research Methods For Busines. WILLEY.

Sjahroeddin, F. (2018). The Role of E-S-Qual and Food Quality on Customer Satisfaction in Online Food Delivery Service. IRONS.

Suhartanto, D., Ali, M. H., Tan, K. H., Sjahroeddin, F., \& Kusdibyo, L. (2018). Loyalty toward online food delivery service: the role of e-service quality and food quality. Routledge.

Sulek, M. J., \& Hansley, L. R. (2004). The Relative Importance of Food, Atmosphere, and Fairness of Wait: The Case of a Full-Service Restaurant. SAGE.

Thomas, V. F. (2019, 9 19). https://tirto.id/. Retrieved from https://tirto.id/nielsen-58-masyarakat-pesanmakanan-via-aplikasi-pesan-antar-eil7

Tim Statista. (2018). $\quad$ https://www.statista.com/. $\quad$ Retrieved from https://www.statista.com/outlook/374/120/online-food-delivery/indonesia\#market-revenue

Triwijarnako, R. (2019, 9 24). https://marketeers.com. Retrieved from https://marketeers.com/58-konsumenpesan-makanan-via-aplikasi-online/

Ueltschy, L. C., Laroche, M., Eggert, A., \& Bindl, U. K. (2007). Service Quality and Satisfaction: An International Comparison of Professional Services Perceptions. Journal of Services Marketing.

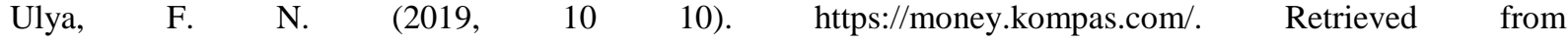
https://money.kompas.com/read/2019/10/10/093000926/nielsen--go-food-dan-grabfood-juarai-layananpesan-antar-di-indonesia?page $=$ all

Wang, O., Somogyi, S., \& Charlebois, S. (2020). Food choice in the e-commerce era. British Food Journal, 122(4), 1215-1237.

Whaley, K. (2015, 9 20). https://www.b2bmarketing.net/. Retrieved from https://www.b2bmarketing.net/en/resources/blog/why-promotions-are-so-important-and-why-you-shouldrun-them-often

Wolf, E. J., Harrington, K. M., Clark, S. L., \& Miller, M. W. (2013). Sample Size Requirements for Structural Equation Models: An Evaluation of Power, Bias, and Solution Propriety. Educational and Psychological Measurement, 913-934.

Woodall, T. (2003). Conceptualising 'Value for the Customer': An Attributional, Structural and Dispositional Analysis. Academy of Marketing Science Review.

Yang, Z., \& Peterson, R. T. (2004). Customer Perceived Value, Satisfaction, and Loyalty: The Role of Switching Costs. Psychology and Marketing, 799-822.

Zehir, C., Sehitoglu, Y., Narcikara, E., \& Zehir, S. (2014). E-S-Quality, Perceived Value and Loyalty Intentions Relationships in Internet Retailers. Science Direct.

Zehir, C., \& Narcikara, E. (2016). E-Service Quality and E-Recovery Service Quality: Effects on Value Perceptions and Loyalty Intentions. Procedia.

Zeitham, V., Bitner, M. J., \& Gremler, D. (2003). Services Marketing. McGraw-Hill Education. 